\title{
Implementation of Parental Involvement in Learning Civic Education
}

\author{
Fitra Waluyandi', Rini Trihastuti ${ }^{2}$, Moh. Muchtarom ${ }^{3}$ \\ ${ }^{1}$ Postgraduate Program in Civic Education Department, Universitas Sebelas Maret, Indonesia \\ ${ }^{2,3}$ Civic Education Department, Universitas Sebelas Maret, Indonesia \\ fitrawaluyandi08@gmail.com,rini3astuti@gmail.com,muhtarom1974@gmail.com
}

\begin{abstract}
Parental involvement in learning civic education is the key to success in learning civic education. Therefore, civic education teachers have a great interest in involving parents in achieving the goals of learning civic education in their class. This study attempts to provide an alternative means of implementing parental involvement in civic education learning. This study aims to classify the roles that can be played by schools, civic education teachers and also parents. From the review of articles on parental involvement theory and models, it can be classified the roles of schools, teachers and parents applicatively.
\end{abstract}

Keywords parental involvement; civic education; family role; teachers role

\section{Introduction}

The most important goal in learning civic education is the formation of civic virtues or the character of smart and good citizens (Winataputra. 2009). Civic virtue is that part of virtue that relates to the connection between citizen and state, or maybe less formal, between citizen and (national / local) community (Blanken, 2012: 10). According to Arif (2017: 3) civic virtue consists of civic disposition, civic commitment and civic culture. Civic is a conscious effort with the aim of developing students' knowledge, attitudes and skills in order to become good citizens, namely citizens who understand, are aware of, and are able to exercise their rights and carry out their duties responsibly (Saputra, 2020). Civic disposition is the character of citizenship, while civic commitment is a citizen's commitment, civic disposition and civic commitment are the basis for citizens to actively participate in government affairs for the formation of a civic culture (Arif, 2017: 3). For that we need a teacher who can guide students by fostering student personalities so that they have good character based on the knowledge they have received. Velea and Farca (2013, p 864) explain that a teacher must be a guide for the moral and affective development of students and young people.

In carrying out these duties, a teacher in general and a teacher of Citizenship Education in particular must receive support from parents. The involvement of parents is very important in order to support the success of teachers in shaping the morale and personality of students well. As explained by Epstein (1995: 701) that families, schools and communities must act without boundaries but as partners for several reasons, especially to help the younger generation achieve success in school and in the future. The teacher is the spearhead of the ongoing teaching and learning process, so that the teacher has an important role as a source of learning in the transformation of the value of science (Iskandar in Kuncoro, 2020).

But in reality, the involvement of parents in their children's education, especially in our country, still faces many obstacles both culturally and regulations. Culturally, the involvement 
of parents in education is still low, as in a study conducted by Majzub and Salim (2011) which found that the involvement of parents in children's education is still very low. In addition, the competence of teachers in establishing communication and cooperation with parents is still minimal. . Linberg (2012) observed that teachers do not feel adequate or they have negative attitudes about dealing with parental involvement. This deficiency arises due to the lack of attention of educational personnel printing institutions that pay attention to these skills. currently there is no teacher candidate education curriculum that includes a curriculum that encourages teachers to involve parents in the education of their students. In the field, there is still an overlap between the roles between parents and teachers in learning, especially civic education learning. In terms of regulation, it is also still weak, as found in Kim's (2018, $\mathrm{p}$ : 149) study which explains that governments in developing countries are not too strong, therefore Kim hopes that society will be the key to achieving educational goals. The family as the smallest part of society has a very important role in supporting the success of children's education, especially in learning civic education.

\section{Review of Literatures}

\subsection{Parental Involvement Theories and Models}

The involvement of parents in the education of their children at school is believed to have a positive impact on the development of children or students in achieving their educational goals in schools, both academic and non-academic, which include moral, spiritual and attitude. Research conducted in Virginia shows that parental involvement has increased student success by as much as $30 \%$ when compared with low-involvement parents, while reading ability has increased by 50\% more than schools with low parental commitment and involvement (Bakker and Denessen, 2007: 188). Whereas Lv, Lv, Yan and Luo found that parental involvement can lead to more favorable child's emotion and academic pro fi les (Lv, Lv, Yan and Luo, 2019: 175).

Current researches on parental involvement that are currently developing emphasize the correlation of parental involvement to student academic performance, such as the research conducted by Midori Otoni (2019) that relates parental involvement to adolescent's academic achievement and aspiration, Lv, Lv, Yan and Luo ( 2019) that studied the relationship between parental involvement in education and chidren's academic / emotion profile. However, there are few studies that emphasize the implementation of parental involvement in a learning field such as civic education.

Bonk, Gijselaers, Ritzen and Gruwel (2018: 12) grouped parental involvement indicator into the two main categories: (1) Home-based involvement refers to what parents do at home to promote their children's learning. De fi nitions of involvement at home included: parents' communication with their child on school issues and other types of home involvement such as monitoring school progress, guidance in learning activities at home or helping with homework. Multiple researchers also considered Parental expectations for their child's academic achievement as a form of involvement., And (2) School-based involvement is basically defined by activities and behaviors parents engaged in at school, such as attending parent-teacher conferences and attending school events. . Common operational definitions of school-based involvement in previous studies also include participation in school activities such as volunteering in the classroom, going on class trips, and participation in school functions. Seginer (2006) maps Parental Involvement into: 


\section{Microsystem}

Home-based involvement, family environment, family structure and family size, physical aspects of the home learning environment

2. Mesosystem

School-based involvement, parent-teacher interaction

\section{Exosystem}

Parents' social networks, workplace, neighborhoods, and educational policy

\section{Macrosystem.}

Social classes, ethnic or religious groups and belief systems of those groups.

A study that emphasizes the implementation of parental involvement was also carried out by Joyce L. Epstein, a researcher from Johns Hopkins University. This model has been adopted by the National Parent Teacher Association to enhance partnerships between schools and families (Mitchell, 2011). The Epstein model is part of the parental involvement model, which is education which is carried out informally at home but is integrated with the school program so that parents must contribute optimally to shape the character of the child. This requires parents to give all their abilities by being actively involved in the education of their children in schools.

The epstein model framework consists of 6 types of parental involvement consisting of: 1. Parenting

Help all families establish home environments to support children as students

\section{Communicating}

Design effective forms of school-to-home and home-to-school communications about school programs and children's progress

3. Voulenteering

Recruit and organize parent help and support

\section{Learning at Home}

Provide information and ideas to families about how to help students at home with homework and other curriculum-related activities, decisions, and planning

\section{Decision Making}

Include parents in school decisions, developing parent leaders and representatives

\section{Collaborating and Community}

Identify and integrate resources and services from the community to strengthen school programs, family practices, and student learning and development.

Epstein himself has further redefined the above six types of parental involvement, describing various examples of the six types of parental involvement, as well as his challenges to the practical steps that can be taken by schools, students and parents. The concept of parental involvement in children's education in schools in this model has made a significant contribution to understanding how families and schools collaborate for student success (Mitchell, 2011: 171). Through this Epstein Model, it will be found that the division of the role of parents as part of society and the role of teachers, especially teachers of Citizenship Education, in achieving the goal of civic education is the formation of good and smart citizens more effectively.

Apart from Epstein, Northern Ireland formed the NICIE (Northern Ireland Council For Integrated Education). NICIE was originally founded on concerns of prejudice and intolerance in Northern Ireland which has divided society into different political, religious, cultural and economic groups. To unite the community, NICE is present by carrying out 
integrated education that carries an education together that is open to various differences in belief or religion, politics, culture and economy. In 1991 NICIE published a Statement of Principles which has a core of Principles of Integrated Education, namely (1) equality, (2) faith and value, (3) Parental Involvement and (4) social responsibility.

1. maintaining significant levels of parental representation on the board of governors (ie in accordance with legislative requirements and structures)

2. creating a forum for parents which cultivates and focuses on parental support for the school

3. establishing appropriate arrangements and procedures for individual and collective communication between parents and: (a) the principal, (b) other members of teaching staff, (c) the governing body; and (d) ensuring that parents are made fully aware of the school's integrated ethos

Based on the above explanation, it can be concluded that Parental Involvement requires conditionings which include supporting factors for the realization of parental involvment in learning, parental involvment principles and technical application in learning. The factors supporting the success of parental involvement in learning consist of family environment, family structure, family size, physical aspects of the learning environment at home, teacher and parent interactions, parents 'social networks, parents' workplace, neighbors and educational policies, class. social, ethnic, religious and group belief systems. While the principles of parental involvement in order to be carried out effectively consist of representation in the school committee, establish a forum between parents and teachers and facilitate communication between parents and various related phat at school. In addition, technical steps are needed in implementing parental involvement in learning. These technical steps can be carried out through mobilizing all the potential of the family to create a home environment that supports children's learning as a student, designing effective communication between parents and teachers regarding school programs and student learning development, involving parents by recruiting and organizing parental assistance and support, providing information or ideas to parents in order to help students at home by providing homework, giving parents the confidence to make decisions.

\subsection{Civic Education and Parental Involvement}

Civic Education in a democracy is education in self government (Branson, 1998). Civic education confronts the young adolescent for the first time in his school experience with a complete view of the citizenship function, as rights and as responsibilities, in a democratic contex. (Allen, 1960). Through civic education children are taught and trained to gain experience in participating in society. In schools young people learn about how to contribute to society through formal and informal learning experiences. (Parker, 2001).

Civic education in a democratic country has a very important position in preparing its young generation to become good citizens. Preparing good citizens can be done through civic education taught in schools. Ideally, the school is a place for young people to accumulate democratic experiences and re fl ect Upon these in addition to experiences acquired else where (Daniels, 2001). Adolescence is a key period for preparing democratic citizens, and schools are expected to foster knowledge, skills and dispositions supporting future engagement and participation (Hahn, 1998).

Civic education taught in schools aims to form citizens who have the knowledge, skills and character that support the continuity and participation of citizens in every aspect of life. To achieve this goal, civic education learning must be well designed so that students can gain experience and feel directly involved in the roles of citizens in a democratic country. In order for students to experience and feel directly, the learning process requires the support of 
various parties, namely schools, families and communities. Sharma, Frederiksen, Malcolm, Rollison and Carter (2018) found the positive impact of community education and engagement efforts in family planning contexts.

Civic education and moral education are closely related as shaping human character. Moral education is in a broader context while civic education is in a smaller scope, which is specifically related to preparing young citizens to be able to face the challenges of life in a modern country such as active participation in state life. Gjorgjeva (2010) explains the relationship between civic education and moral education by saying that moral education has a broader area and that civic education is only one segment covering one area of moral education. So civic education is one part of moral education.

Civic education is a part of moral education, so the involvement of parents is needed. Kurniawan (2015) concluded that character building of elementary school children can be done by consistently instilling character values both when the child is in the family environment, school environment, and community environment. Parental involvement as described above plays a very important role in learning civic education in schools. Educating for citizenship implies an intentional and systematic educational effort, across the whole school and involving it as a community, with the ultimate goal of promoting a global enrichment of students as people and preparing them for active participation in society (Fonseca, 2003).

\section{Research Method}

This study aims to break down the overlapping roles between teachers and parents by classifying the roles of parents and the roles of teachers in learning civic education. For this reason, the researcher examines various theories and models of parental involvement that support parental involvement in children's education then based on this theory tries to reduce it in the realm of its implementation. With the classification of these roles, it is hoped that parents and teachers can work together in giving birth to young children who have good citizen character.

\section{Discussion}

The division of roles between parents and teachers in civic education learning is very important. Civic education as a subject taught in class has the characteristics of forming the character of citizens so that learning must provide opportunities for students to learn to be directly involved in participation in society. The inculcation of citizen character in schools by teachers can be followed up by parents at home by providing opportunities for children to be directly involved in the community. This division of roles can be done by making a general agreement about the roles that can be played by each party to support good cooperation and partnership between schools and parents.

To make this classification the researcher examines several theories and models that can be used as a basis for this classification. The theory and model of parental improvement used are Seginer, Epstein and NICIE. 
Table 1. Main Issues of Seginer, Epstein and NICIE

\begin{tabular}{ll}
\hline $\begin{array}{c}\text { Theories / } \\
\text { Models }\end{array}$ & \multicolumn{3}{c}{ Main Issue in Parental Involvement } \\
\hline Seginer & $\begin{array}{l}\text { Maping on Parental involvement into } 4 \text { kinds, there are: microsystem, } \\
\text { mesosystem, exosytem and macrosystem. }\end{array}$ \\
\hline Epstein & $\begin{array}{l}\text { Six kinds of parental involvement: parenting, communicating, } \\
\text { voulentering, learning at home, decision making, collaborating and } \\
\text { community }\end{array}$ \\
\hline NICIE & $\begin{array}{l}\text { Effective parental involvement in the life and work of the school by: } \\
\text { maintaining significant levels of parental representation on the board of } \\
\text { governors, creating a forum for parents which cultivates and focuses } \\
\text { parental support for the school, establishing appropriate arrangements } \\
\text { and procedures for individual and collective communication between } \\
\text { parents and principal, other member of teaching staff, the governing } \\
\text { body and ensuring that parents are made fully aware of the school's } \\
\text { integrated ethos }\end{array}$ \\
\hline
\end{tabular}

Based on table 1 above, it can be said that Parental involvement from Seginer discusses the factors in parental involvement, Epstein discusses the technical implementation of parental involvement by teachers and parents. Meanwhile, NICIE emphasizes how to communicate school programs and how parents can have easy access to various information to schools, especially regarding the development of their children. Seginer, Epstein and NICIE still need to be clarified again with implementation, the various forms of parental involvement above require appropriate further steps so that parental involvement in civic education learning can go hand in hand so that the cultivation of knowledge, attitudes and skills of citizens that are expected to be carried out properly .

Parental involvement in learning civic education is needed because civic education is a part of moral education. As part of moral education, civic education must be able to form good morale for citizens. To form good citizen morale, parental involvement is needed.

Table 2. Parental involvement, Teacher of Civic Education, Moral Education and Civic

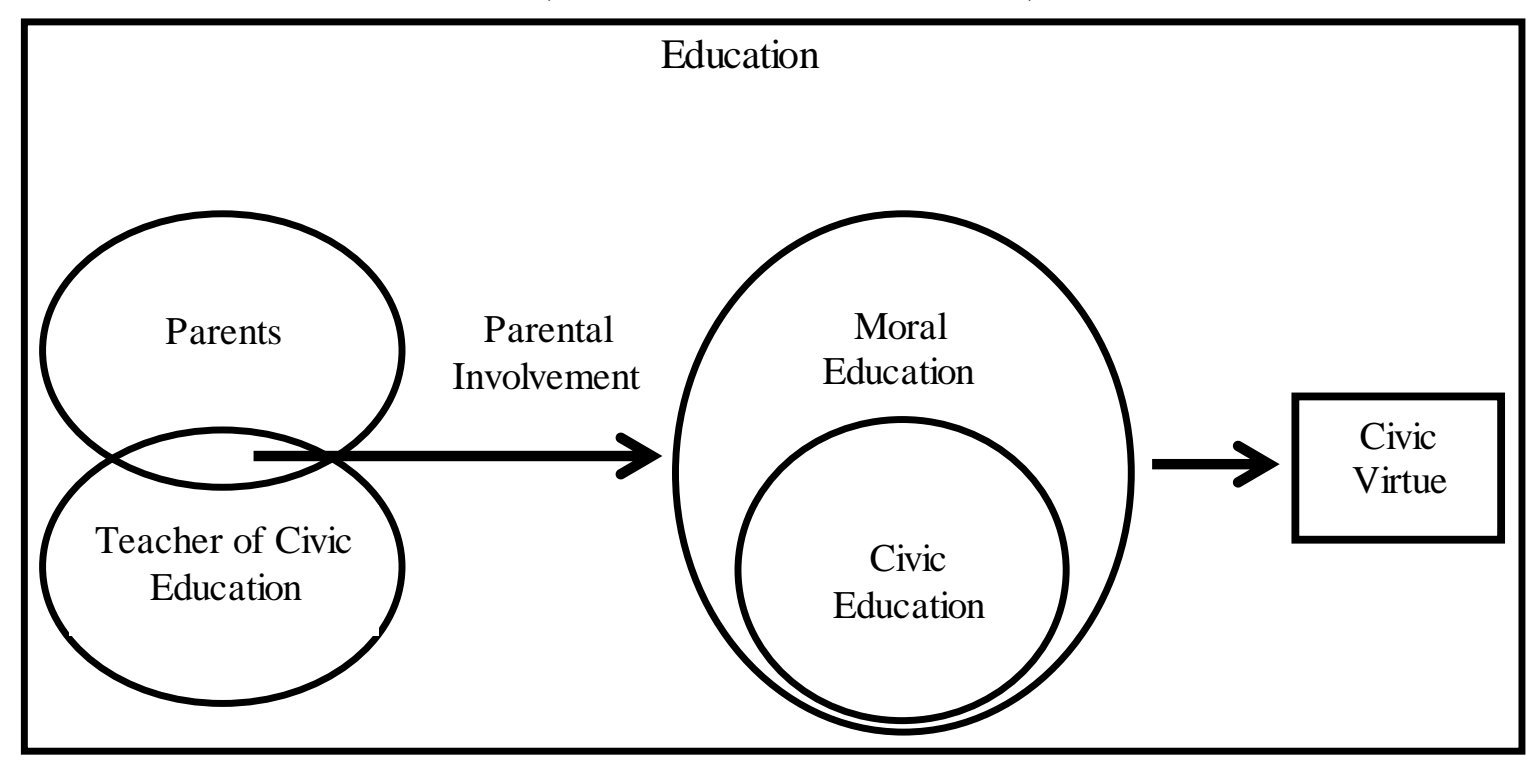


Table 2 explains that parents and civic education teachers collaborate as partners in civic education learning to help students learn and achieve moral citizenship, namely civic virtue. Collaboration between parents and civic education teachers can be carried out through several alternative activities, each of which plays a role with the same goal of training and fostering students to become good citizens. Collaboration between parents and civic education teachers can be carried out with various alternative activities. The examples of activities that can be carried out are as follows:

1. Seginer

Activities that can be done by parents:

- et an example related to good citizens

- create an environment that supports good civic practice, provides opportunities and encourages students to be involved in youth / community organizations

- provide learning in class, establish communication with civic education teachers

- provide recommendations for teachers to be able to access workplaces, colleagues, neighbors and other parents' social networks in the context of civic education learning

- teach religion and how to worship, read holy books, practice religious teachings

2. Epstein

Activities that can be done by parents:

\section{- Parenting}

Alternative activities: condition the home atmosphere that encourages children to learn comfortably, equip themselves with parenting knowledge, support and help students by providing adequate nutrition, open themselves to schools / teachers or home visits conducted by civic education teachers.

- Communicating

Alternative activities: conducting regular and periodic meetings with civic education teachers, checking homework and providing comments and submitting the results of these examinations to civic education teachers, giving time and caring for children's development reports in achieving civic education goals, actively communicating with civic education teachers through various communication media, follow and understand various information related to civic education learning carried out in the classroom including learning programs, learning activities and also civic education teacher policies.

- Volunteering

Alternative activities: supporting civic education learning programs to help civic education teachers, including inviting other parents to care for and support learning programs, collecting parental potential data that can be used to support civic education learning, sharing information related to learning programs civic education, conduct joint supervision of the sustainability of the program

- Learning at Home

Alternative activities: providing time to study textbooks according to the child's level / class, accompanying children in learning at home or doing homework, helping children solve learning problems / difficulties at home, checking homework implementation, discussing with children about learning that has been conducted in the civic education class, creating a civic education study program during the end of semester holidays or the end of the school year

- Decision making

Alternative activities: be active in parent meetings or the parents forum, such as school committees, parent-teacher forums etc, become a committee member of the school committee - Collaborating with Community 
Alternative activities: informing students and parents about communities that can support civic education learning, exploring possibilities for collaboration with various communities, connecting communities with civic education teachers, establishing partnerships with various communities in order to support civic education learning

3. NICIE

- Establish a parent and teacher forum and encourage parents to be actively involved in it

- Communicating with civic education teachers both individually and collectively in order to run partnerships to support civic education learning

- Establishing collaborations and partnerships with various institutions both government and private as an effort to support civic education teachers

\section{Conclusion}

Parental involvement in learning civic education is very important considering that civic education is a part of moral education which is responsible for preparing students to become good citizens. Parental involvement can be implemented through an agreement between parents and teachers or schools so that teachers and parents have guidance in their involvement in preparing the younger generation who have good citizen character in all aspects both as individuals and as part of society. The division of roles between schools, teachers and parents in this study is expected to be a guide in implementing parental involvement in civic education learning, although it does not rule out that this division of roles can be negotiated by various related parties.

The implementation of the theory and model above can be classified as the division of roles between schools, teachers and parents as follows: (1) The role of schools, (2) the role of civic education teachers and (3) the roles of parents. These roles can be detailed as follows:

1). The role of the school

a. forming a committee

b. provide a channel of communication between teachers and parents

c. provide knowledge to parents about appropriate parenting patterns so that they can work synergistically with civic education teachers and learning carried out in the classroom

2). The role of the teacher

a. civic education teachers provide a channel for parental involvement in the learning process (such as: inviting parents as sources / learning resources, encouraging parents to be able to assist students in doing assignments given from school, communicating and encouraging parents to be role models in good citizenship

b. communicate with parents about parental involvement in the formation of good citizen character

c. understanding parents in parenting includes understanding the role of parents in their children's learning

d. involve parents actively in learning

e. looking for solutions and providing advice to parents who do not want to or have not been actively involved in shaping the character of citizens through civic education

f. provide time for coordination and consultation on the development of children's citizenship behavior

3). The role of parents

a. establish a school committee / parent and teacher forum or, if already there, are actively involved in the school committee / parent and teacher forum 
b. To provide support to the school in the education of their children to set an example in the correct state life

c. communicate according to procedures both individually and collectively

d. encouraging good performance from the teacher / school

e. actively encouraging children to familiarize themselves with the correct citizen character

f. equip themselves with parenting / parenting education

g. provide time for coordination and consultation on child development

h. provide consideration in the implementation of activities

i. carry out supervision of schools and also civic education teachers

\section{References}

Allen, Jack. (1960). The Role of Ninth Grade Civics in Citizenship Education. The High School Journal, Vol. 44, No. 3 (Dec., 1960), pp. 106-111

Arif, Dikdik Baehaqi.(2017). Pengembangan Kebajikan Kewargaan (Civic Virtue) dalam Masyarakat Multikultural Indonesia: Peran Pendidikan Kewarganegaraan. Journal Civics \& Social Studies Vol.1 No. 1. Juni 2017

Bakker, Joep and Denessen, Eddie. (2007). The concept of parent involvement. Some theoretical and empirical considerations. International Journal about Parents in Education 2007, Vol..1, No. 0, 188-199

Blanken, B.D.B, (2012). The Good Liberal Citizen: Why Citizens can be both Free and Virtuos. $\quad$ Retrieved from https://openaccess.leidenuniv.nl/bitstream/handle:https://openaccess.leidenuniv.nl/bitstr eam/handle/1887/19286/MSc\%20Thesis\%20BDB\%20Blanken.pdf?sequence=1

Boonk, Lisa; Gijselaers, Hieronimus J.M; Ritzen, Henk and Gruwel, Saskia Brand (2018). A review of the relationship between parental involvement indicators and academic achievement. Educational Research Review 24 (2018) 10-30

Daniels, H.(2001). Vygotsky and pedagogy. London: Routledge Falmer

Epstein,J.L.(1995).School/family/community partnerships: Caring for the children we share. Phi Delta Kappan, 76(9), 701-712.

Gainous, Jason and Marten, Allison M. (2012). The Effectiveness of Civic Education: Are "Good" Teachers Actually Good for "All" Students? American Politics Research40(2) $232-266$

Gjorgjeva, Emilija Petrova. (2010). Democratic society and moral education. Procedia Social and Behavioral Sciences 2 (2010) 5635-5640

Hahn, Carole (1998). Becoming Political. Albany: State University of New York Press

Kim, Sun Won (2018) Parental involvement in developing countries: A meta-synthesis of qualitative research. International Journal of Educational Development 60 (2018) 149156

Kuncoro, R.Y., Triyanto, Triastuti, R. (2020). Constraints in the Implementation of Digital Ethics in SMA Muhammadiyah 1 Surakarta. Budapest International Research and Critics in Linguistics and Education (BirLE) Journal Vol 3 (1): 157-163.

Kurniawan, Machful Indra. (2015). Tri Pusat Pendidikan Sebagai Sarana Pendidikan Karakter Anak Sekolah Dasar. JOURNAL PEDAGOGIA ISSN 2089 -3833 Volume. 4, No. 1, Februari 2015

Lv, Bo; Lv, Lijie; Yan, Zhonglian and Luo, Liang. (2019). The relationship between parental involvement in education and children's academic/emotion profiles: A person-centered approach. Children and Youth Services Review 100 (2019) 175-182 
Majzub, Rohaty Mohd. And Salim, Elis Johannes Hendry. (2011). Parental involvement in selected private preschools in Tangerang, Indonesia. Procedia Social and Behavioral Sciences 15 (2011) 4033-4039

Margaret Stimmann Branson(1998). The Role of Civic Education. A Forthcoming Education Policy Task Force Position Paper from the Communitarian Network.

Mitchell, Marilyn Price. (2011) . Book Review of School, Family, and Community Partnerships: Preparing Educators and Improving Schools. The School Community Journal, 2011, Vol. 21, No. 1

Parker, W.C. (2001). Educating democratic citizen: A broad view. Theory into Practice. 40(1), $6-13$

Saputra, I., Muchtarom, M., and Triyanto. (2020). Social Engagement as an Initial Capital for the Development of Civic Engagement Students in Boarding Schools. Budapest International Research and Critics in Linguistics and Education (BirLE) Journal Vol 3 (2): $820-827$.

Seginer, Rachel. (2006). Parents' Educational Involvement: A Developmental Ecology Perspective. Parenting-science and Practice - PARENT-SCI PRACT. 6. 1-48. 10.1207/s15327922par0601_1.

Sharma, Anjana E; Frederiksen, Brittni N; Malcolm, Nikita M; Rollison, Julia M and Carter; Marion W. (2018). Community Education and Engagement in Family Planning: Updated Systematic Review. Am J Prev Med 2018;55(5):747-758

Velea, Simona and Farca, Speranta. (2013). Teacher's responsibility in moral and affective education of children. 5th International Conference EDU-WORLD 2012 - Education Facing Contemporary World Issues

Winataputra, Udin. (2009). Pendidikan Kewarganegaraan Sebagai Suatu Sistem Pengetahuan Terpadu Academic Positioning Dari Ruu Pendidikan Kewarganegaraan. Bahan Diskusi dalam Seminar Terbatas RUU Pendidikan Kewarganegaraan dalam Kebijakan PertahananAspek Perundang-undanganTanggal 16 Oktober 2008 di Gedung Suprapto, Aula Bela Negara,Ditjen Pothan, Dephan Jakarta 